\title{
Przekłady Biblii na język włoski (XX wiek)
}

Omawiając XX-wieczne tłumaczenia Biblii na język włoski musimy dokonać pewnego istotnego rozróżnienia: istnieje wielość tłumaczeń i wielość edycji - te ostatnie są liczniejsze, gdyż ten sam przekład może ukazać się w odmiennych formach. Egzegeza współczesna dochodzi do głosu przede wszystkim w tłumaczeniach i w nowych komentarzach, które dołączane są niekiedy także do wcześniejszych, starszych wydań. Fakt ten nie wstrzymał powstawania nowych przekładów, wręcz przeciwnie - w ostatnich dziesięcioleciach ich liczba zdecydowanie wzrosła.

W 1902 roku w Watykanie powstała specjalna inicjatywa pod nazwą Pia Società S. Girolamo ${ }^{1}$. Tworzyła ją grupa biblistów, wśród których był także przyszły kardynał Giovanni Mercati (1866-1957). Stowarzyszenie stało się pierwszą organizacją we Włoszech, która promowała rozpowszechnianie i czytanie Biblii w rodzinach. Jego staraniem rozprowadzono po bardzo przystępnej cenie i w milionowych nakładach Il santo Vangelo di N. S. Gesù Cristo e gli Atti degli Apostoli². Przyczynkiem do wydania tego rodzaju publikacji był kryzys życia chrześcijańskiego i nieznajomość słowa Bożego we Włoszech ${ }^{3}$. W dzieło zaangażowani

${ }^{1}$ Pobożne Stowarzyszenie św. Hieronima. Podobną rolę odgrywała Pia Società San Paolo di Alba, później Edizioni Paoline, a obecnie Edizioni San Paolo - por. C. Buzzetti, C. Ghidelli, La traduzione della Bibbia nella Chiesa italiana. Il Nuovo Testamento, Cinisello Balsamo 1998, 110; A. Vaccari, Bibbia, [w:] Enciclopedia Italiana, Roma 1930, 903.

${ }^{2}$ Pozycja o rozmiarach $9,30 \times 15,50 \mathrm{~cm}$ liczyła 430 stron tekstu i 20 stron wprowadzenia. W pierwszym roku rozprowadzono 180 tys. egzemplarzy. Ostatnie wydanie ukazało się w 1977 roku już z tekstem tłumaczenia Konferencji Episkopatu Włoch i było 526. z kolei.

${ }^{3}$ Por. G. Danieli, La Bibbia..., [w:] La Bibbia in italiano tra medioevo e rinascimento. Atti del Convegno internazionale, Firenze, Certos a del Galluzzo, 8-9 novembre 1996, a cura di L. Leonardi, Tavarnuzze-Firenze 1998, 36-40. 
byli m.in. G. Clementi (tłumaczenie), P. Genocchi (zwięzłe komentarze, przypisy), P. Semeria (wprowadzenia, prezentacje).

Od połowy XX wieku katolicy włoscy coraz częściej zaczęli tłumaczyć teksty biblijne bezpośrednio z języków oryginalnych, a nie jak dotychczas z Wulgaty. Taki stan rzeczy był wynikiem dwóch przesłanek: sprzyjający klimat odnowy po Soborze Watykańskim II oraz rozwój krytycznych studiów biblijnych ${ }^{4}$.

Poniżej omówimy w porządku chronologicznym wszystkie najważniejsze przekłady Biblii, które zostały wydane drukiem w języku włoskim w XX wieku (jest ich 27), nie uwzględniamy jednak z założenia tłumaczeń i przekładów mało rozpowszechnionych lub opracowań o charakterze częściowym lub specjalistycznym (np. tylko ewangelie, tylko psalmy, Biblie dla dzieci itp.).

Tam, gdzie w opisie dzieła brak dodatkowych adnotacji, mamy do czynienia z wydaniem jednotomowym, w przypadku kilku edycji, omówiona jest jedna z nich. Oznaczenie [*] wskazuje, że dane wydawnictwo rozpowszechniane jest także w innych formach.

La Sacra Bibbia. Versione Riveduta - miejsce i data: Rzym 1924nn; wydawca: Società Britannica e Forestiera ${ }^{5}\left[{ }^{*}\right.$ ]; źródło: przekład z języków oryginalnych; nie zawiera ksiąg deuterokanonicznych; wprowadzenia: brak; u dołu strony: bardzo zwięzłe przypisy i odsyłacze (z zaznaczeniem w tekście biblijnym). Wydanie jest owocem prac komisji działającej pod przewodnictwem G. Luzziego. Stanowi korektę wersji Diodati.

La Bibbia tradotta dai testi originali e annotata - miejsce i data: Florencja 1921-1930; wydawca: Sansoni; Fides et Amor ${ }^{6}$ (pierwszych pięć tomów zostało wydanych przez Sansoni); źródła: przekład z języków oryginalnych; tłumaczenie: G. Luzzi, waldens; zawiera księgi deuterokanoniczne; u dołu strony: przypisy i odnośniki; poza tekstem: fotografie i mapy geograficzne. Tom I stanowi wprowadzenie ogólne i przesadnie szeroki komentarz. W interpretacji dostrzegalne są skłonności do teologii

${ }^{4}$ Por. C. Buzzetti, La Bibbia in Italia, tra i cattolici, a partire dal XV secolo, [w:] La Bibbia e l'Italia, introduzione di G. Platone, Torino 2004, 21.

${ }^{5}$ Por. C. Buzzetti, C. Ghidelli, La traduzione..., dz. cyt., 111; P. J. Achtemeier, Bibbia in lingua italiana, [w:] Il Dizionario della Bibbia, P. J. Achtemeier, P. Capelli, Bologna 2003, 136.

${ }^{6}$ Por. C. Buzzetti, C. Ghidelli, La traduzione..., dz. cyt., 111; A. Vaccari, Bibbia, art. cyt., 903. 
liberalnej. Język pełen toskanizmów. Edycja jest dziełem paralelnym do rewizji przekładu Diodati.

La Sacra Bibbia - miejsce i data: Florencja 1929; wydawca: Libreria Editrice Fiorentina de la Card. Ferrari ${ }^{7}$; źródła: przekład z Wulgaty z wyjątkiem tych fragmentów, w których wersja łacińska nie oddawała pierwotnego znaczenia hebrajskiego lub greckiego (jeśli zachodziła potrzeba dodania jakiegośs słowa, zostało ono umieszczone w nawiasach kwadratowych); tłumaczenie (i przygotowanie): A. Mercati, G. Bonaccorsi, G. Castaldi, G. Giovannozzi, G. Mezzacasa, F. Ramorino, G. Ricciotti, G. M. Zampini; u dołu strony: nieliczne przypisy; wprowadzenia: ogólne, opis korzystania z Biblii. Prezentowana jest jako pierwsze tłumaczenie w języku włoskim od czasu A. Martiniego. Jej wydanie miało zrównoważyć edycje propagowane i promowane we Włoszech przez protestantów.

La Sacra Bibbia - miejsce i data:Florencja 1939-1940 (najpierw ukazała się $\mathrm{w}$ wielu zeszytach, następnie $\mathrm{w}$ jednym tomie); wydawca: Salani ${ }^{8}$; źródła: przekład z łacińskiej Wulgaty; tłumaczenie: G. Ricciotti i inni; wprowadzenia: ogólne i do części; u dołu strony: bardzo zwięzłe przypisy; w dodatku: indeks analityczny do Starego Testamentu (33 strony) i do Nowego Testamentu (36 stron). Edycja jest w zasadzie odtworzeniem (z pewnymi zmianami) tekstu przekładu opisanego wyżej, do którego dodano wprowadzenia i przypisy G. Ricciottiego.

La Sacra Bibbia - miejsce i data: Turyn 1931; wydawca: Berutti9; źródła: przekład z Wulgaty; wprowadzenia: ogólne i do części, do ksiąg; u dołu strony: bardzo zwięzłe przypisy; w dodatku: mapy geograficzne. Jest to skorygowana wersja A. Martiniego opracowana przez M. Salesa.

La Sacra Bibbia - miejsce i data: Alba 1931nn; wydawca:Paoline di Alba ${ }^{10}$; źródła: przekład z Wulgaty; tłumaczenie: E. Tintori OFM i współpracownicy ${ }^{11}$; wprowadzenia: ogólne, opis korzystania z Biblii; u dołu strony: zwięzłe przypisy; w dodatku: indeks analityczny (66 stron). Wyrażenia wyjaśniające dodane do tekstu w celu jego łatwiejszego zrozumienia lub nie tłumaczone dosłownie umieszczone są w nawiasach okrągłych.

\footnotetext{
${ }^{7}$ Por. C. Buzzetti, C. Ghidelli, La traduzione..., dz. cyt., 111.

${ }^{8}$ Por. tamże, 112.

${ }^{9}$ Por. tamże.

${ }^{10}$ Por. tamże.

${ }^{11}$ Każdy tom posiada wykaz wszystkich tłumaczy.
} 
Pozycja nie ma charakteru krytycznego i nie zawiera nowości, ma być słowem Bożym skierowanym do szerokich kręgów odbiorców, ma zatem charakter typowo duszpasterski, także we wprowadzeniach i w formie ogólnej wydania. Edycja nosi podtytuł Versione Italiana della Vulgata e commento pastorale.

La Sacra Bibbia - miejsce i data: Mediolan-Rzym-Florencja 1957-1958 (wydanie 10-tomowe), Florencja 1961 (wydanie 1-tomowe); wydawca: Salani ${ }^{12}$; źródła: przekład z języków oryginalnych; tłumaczenie: A. Vaccari (red.), G. Berini, G. Mezzacasa, A. Parenti, T. Piatti, G. B. Re, G. Rinaldi, F. Scerbo, M. Tellina, M. Toccabelli, L. Tondelli, R. Tramontano i inni; wprowadzenia: ogólne, do części, do ksiąg, opis korzystania z Biblii; u dołu strony: przypisy; dodatki: we wszystkich tomach dodatek krytyczny zawierający warianty tekstowe z uzasadnieniem decyzji tłumaczy, w sześciu tomach dodatek pozakanoniczny, cały tom X to indeksy (m.in. analityczny, 205 stron), w tomie VIII wykaz ewangelii niedzielnych i świątecznych; poza tekstem: tablice (ponad 50 rysunków i fotografii), mapy geograficzne (około 10). Podstawą przekładu były wydania krytyczne ${ }^{13}$. Wykorzystano też najnowsze osiągnięcia w dziedzinach biblijnych, zwłaszcza w leksykografii. W tłumaczeniu przyjęto zasadę św. Hieronima: nie słowo za słowo, lecz sens za sens. Rolę tradycyjnego komentarza pełnią przypisy opracowane przez zespół biblistów z Papieskiego Instytutu Biblijnego w Rzymie. Idą one w trzech kierunkach: zmniejszają trudności wynikające z lektury tekstu, wskazują miejsca, w których orędzie Biblii jest potwierdzone przez zabytki starożytności, zwracają uwagę na najważniejsze elementy dogmatyczne i moralne. Edycja stanowi realizację założenia, że pierwszym i najlepszym komentarzem do Biblii jest jej dobre tłumaczenie ${ }^{14}$.

La Sacra Bibbia [*] - miejsce i data: Rzym 1958; wydawca: Edizioni Paoline ${ }^{15}$; źródła: przekład z języków oryginalnych; tłumaczenie: G. Robaldo, G. Cortoldi, F. Pasquero, V. Mulone, F. Nardoni; wprowadzenia:

${ }^{12}$ Por. C. Buzzetti, C. Ghidelli, La traduzione..., dz. cyt., 112.

${ }^{13}$ Stary Testament - tekst masorecki; LXX - wyd. A. Rahlfs; Nowy Testament - wyd. A. Merk.

${ }^{14}$ Por. też wprowadzenie zamieszczone w tym wydaniu.

${ }^{15}$ Por. C. Buzzetti, C. Ghidelli, La traduzione..., dz. cyt., 113; P. J. Achtemeier, Bibbia in lingua italiana, art. cyt., 136. 
ogólne, do ksiąg; u dołu strony: przypisy; w dodatku: indeks analityczny (31 stron). Inicjatorem wydania był G. Alberione, założyciel Pia Società S. Paolo ${ }^{16}$. Ma ono charakter duszpasterski i przeznaczone jest dla każdego czytelnika. Długotrwałe i uważne studium specjalistów z dziedzin biblijnych pozwoliło dobrać wyrażenia i słowa najbardziej trafne i na tyle proste, by umożliwiały zrozumienie tekstu świętego przeciętnemu czytelnikowi. Tekst nie rozczaruje jednak nawet wykształconego odbiorcy. Dzięki uzupełniającym przypisom czytelnik ma ułatwioną możliwość poznania Boga ${ }^{17}$. Biblia ta została objęta szeroką kampanią reklamową, przede wszystkim w 1962 roku, tak aby słowo Boże drukowane dotarło do jak największej liczby odbiorców ${ }^{18}$.

La Bibbia - miejsce i data: Florencja 1960; wydawca: Fiorentina ${ }^{19}$; źródła: przekład zjęzyków oryginalnych; tłumaczenie: F. Nardoni; wprowadzenia: ogólne; u dołu strony: krótkie odnośniki i przypisy; w dodatku: wykaz imion i głównych zagadnień (5 stron), chronologiczny schemat głównych wydarzeń (2 strony). Tłumaczenie wyjątkowo dosłowne, przeznaczone przede wszystkim dla studentów i grup biblijnych; pełni rolę pierwszej pomocy w zbliżeniu się do Biblii. Nie podano, czy to wydanie różni się od wcześniejszych; analiza tekstu potwierdza jednak, że w wielu przypadkach tak właśnie jest.

La Sacra Bibbia tradotta dai testi originali commentata - miejsce i data: Casale M. 1961 (wydanie 3-tomowe) i 1963 (wydanie 1-tomowe); wydawca: Marietti ${ }^{20}$; źródła: przekład z tekstów oryginalnych; tłumaczenie: S. Garofalo (red.), F. Vattioni (koordynator Starego Testamentu), L. Algisi (koordynator Nowego Testamentu) i inni ${ }^{21}$; wprowadzenia: do części, do ksiąg; u dołu strony: obszerne przypisy; w dodatku: tablice chronologiczne (8 stron); poza tekstem: ponad 200 stron ilustracji. Tłumacze wykorzystali najnowsze osiągnięcia z dziedziny filologii, krytyki literackiej, krytyki historycznej. Język przekładu jest surowy, ale nie skąpy.

\footnotetext{
${ }^{16}$ Por. wprowadzenie do wydania z 1968 roku.

${ }^{17}$ Por. tamże.

${ }^{18}$ Por. P. J. Achtemeier, Bibbia in lingua italiana, art. cyt., 136.

${ }^{19}$ Por. C. Buzzetti, C. Ghidelli, La traduzione..., dz. cyt., 113.

${ }^{20}$ Por. tamże.

${ }^{21}$ D. Baldi, G. Castellino, P. Colella, E. Da S. Marco, M. Erbetta, U. Gallizia, L. Moraldi, G. F. Nolli, N. Palmarini, A. Penna, G. Ronaldi, A. Romeo, G. Sadarini, F. Spadafora, Teodorico da Castel S. Pietro, C. Zedda.
} 
Celem wszystkich zabiegów było oddanie w języku włoskim klimatu języków oryginalnych, starano się zatem tam, gdzie to było możliwe, o zachowanie wierności nie tylko znaczeniu, ale i frazom oraz duchowi pierwotnych konstrukcji. Imiona osób i nazwy miejsc (o ile nie weszły już na stałe do obiegowego języka włoskiego) zostały zaczerpnięte z języków oryginalnych, a nie np. z łaciny) ${ }^{22}$. Edycja daje zwłaszcza laikom tekst pozwalający na właściwe i twórcze poznawanie Biblii. Dostarcza materiału gruntownie opracowanego, który respektuje zarówno księgę świętą, jak i współczesnego czytelnika.

La Sacra Bibbia - miejsce i data: Turyn 1963 (wydanie 3-tomowe); wydawca: Unione Tipografica-Editirce Torinese ${ }^{23}$; źródła: przekład z języków oryginalnych; tłumaczenie: E. Galbiati, A. Penna, P. Rossano; wprowadzenia: do części, do ksiąg; u dołu strony: przypisy (trafne i wystarczające); poza tekstem: około 90 fotografii i 5 map geograficznych; brak prezentacji, która podawałaby motywy, cele i sposób przekładu. Tłumaczenie bardzo zrównoważone, brak parafraz. Niezwykle życzliwie przyjęte przez czytelników i ekspertów, zwłaszcza w sektorze krytyki literackiej ze względu na wierność oryginałowi. Zaletą tego wydania jest również ujednolicenie tekstu przekładu ${ }^{24}$. Tekst tej edycji stał się później podstawą do przekładu Biblii oficjalnie przyjętego i zatwierdzonego przez Konferencję Episkopatu Włoch.

La Sacra Bibbia - miejsce i data: Mediolan 1964; wydawca: Garzanti ${ }^{25}$; źródła: przekład z języków oryginalnych; tłumaczenie: B. Mariani OFM i inni bibliści franciszkańscy ${ }^{26}$; wprowadzenia: ogólne, historyczno-geograficzne ${ }^{27}$ (27 stron), do części, do ksiąg; u dołu strony: przypisy i odnośniki; w dodatku: mapy geograficzne (16 stron), indeks anali-

${ }^{22}$ Niestety język włoski nie zna niektórych dźwięków istniejących w językach oryginalnych. Opuszczono zatem znaki diakrytyczne i starano sięje zastą̧ić wyrażeniami równoznacznymi, które funkcjonują już w międzynarodowym słownictwie biblijnym - por. Wprowadzenie.

${ }^{23}$ Por. C. Buzzetti, C. Ghidelli, La traduzione..., dz. cyt., 113; P. J. Achtemeier, Bibbia in lingua italiana, art. cyt., 136.

${ }^{24}$ Por. E. D’Antonio, La traduzione..., dz. cyt., 100.

${ }^{25}$ Por. C. Buzzetti, C. Ghidelli, La traduzione..., dz. cyt., 113-114.

${ }^{26}$ Por. wykaz tłumaczy.

${ }^{27}$ Obejmuje historię biblijną od początku do epoki Chrystusa i stanowi oryginalne, całościowe i syntetyczne opracowanie historii świętej - por. Wprowadzenie, XIII. 
tyczny (65 stron). Komentarz uwzględnia najnowsze zdobycze nauk świeckich i religijnych (krytyka literacka, historia biblijna, historia, archeologia, geografia, typografia itp.). Przypisy dostarczają wyczerpujących informacji doktrynalnych i historycznych, wyjaśniają także kontrowersje krytyczne i egzegetyczne pojawiające się przy interpretacji tekstu ${ }^{28}$. Celem autorów był przekład współczesny i wierny zarazem. Aby go osiągnąć, starano się (zwłaszcza w przypadku języka hebrajskiego) zachować formy syntaktyczne i wyrażenia semickie. Imiona hebrajskie (z wyjątkiem tych, które weszły już do obiegowego języka włoskiego) zostały zapisane w transkrypcji uproszczonej, a nie naukowej. Ujednolicono też wartości miar, ciężarów, monet, dostosowując je do obowiązujących ogólnie kryteriów ${ }^{29}$.

Traduzione del nuovo mondo delle Scritture - miejsce i data: Nowy Jork 1967; wydawca: Watch Tower Brooklyn ${ }^{30}$ [*]; źródła: tłumaczenie wydania angielskiego z 1961 roku; wprowadzenia: ogólne; opis posługiwania się Biblią zawierający wykaz ksiąg biblijnych; u dołu strony: bardzo krótkie przypisy; na marginesie: odnośniki (zarówno przypisy jak i odnośniki są zaznaczone w tekście); w dodatku: indeks słów biblijnych (63 strony), indeks terminów umieszczonych w przypisach dolnych (6 stron), omówienie siedmiu szerszych zagadnień, rysunki i mapy geograficzne (35 stron). Biblia Świadków Jehowy. Została wydana ponownie w 1987 roku (na bazie wydania angielskiego z 1984 roku), ale w konsultacji ze starożytnymi tekstami hebrajskimi i greckimi. Cechą charakterystyczną tego wydania jest używanie określenia Jehowa na oznaczenie imienia Boga ${ }^{31}$. Tekst posiada liczne wtrącenia: słowa, które uzupełniają tekst włoski (w nawiasach kwadratowych pojedynczych); interpolacje (w nawiasach kwadratowych podwójnych). Autorzy podkreślają, że jest to tłumaczenie najwierniejsze z możliwych (niemalże słowo w słowo); odstępstwa pojawiają się tylko tam, gdzie przekład dosłowny nie jest wystarczająco zrozumiały. Zatroszczono się o swoistego rodzaju jednakowość tłumaczenia, ustalając znaczenie najważniejszych terminów i starając się je zachować wszędzie tam, gdzie występują one w języku

\footnotetext{
${ }^{28}$ Por. tamże.

${ }^{29}$ Por. tamże.

${ }^{30}$ Por. C. Buzzetti, C. Ghidelli, La traduzione..., dz. cyt., 114.

${ }^{31}$ Por. tamże.
} 
oryginalnym. Postanowiono nie uwspółcześniać wyrażeń dosłownych, dlatego czytelnik napotyka sporą ilość zwrotów idiomatycznych, zarówno hebrajskich jak i greckich. Brak w niej ksiąg deuterokanonicznych.

La Sacra Bibbia Concordata - miejsce i data: Mediolan 1968 (dwa wydania: 2- i 1-tomowe); wydawca: Mondadori32; źródła: przekład z języków oryginalnych; tłumaczenie: S. Cavaletti, A. Dutanti, A. Mattioli, L. Moraldi, B. Prete, A. Riccardi i inni; redakcja: S. Cipriani, G. Gamberini, P. P. Grassi, P. Kizeridis, F. Montagnini, A. Soggin, E. Toaff i inni; wprowadzenia: ogólne, opis posługiwania się Biblią, do części, do ksiąg - jest to wprowadzenie historyczno-literackie oparte na najnowszych wynikach dyscyplin historycznych, archeologicznych, filologicznych i językoznawczych ${ }^{33}$; u dołu strony: zwięzłe przypisy; w dodatku: 16 map geograficznych lub schematów, obszerny indeks analityczny z wykazem imion, rzeczy, miejsc paralelnych; poza tekstem: ponad 60 tablic (reprodukcje obrazów o tematyce biblijnej). Przekład uwzględnia kanon aleksandryjski ${ }^{34}$ i zawiera wszystkie księgi uznawane za natchnione przez Kościół katolicki i prawosławny. Jest owocem współpracy chrześcijan (katolików, protestantów, prawosławnych) oraz żydów ${ }^{35}$, ale zasady tej współpracy i jej zakres nie zostały przez wydawcę przedstawione. Rygor naukowy edycji gwarantuje krytyka dokonana przez uznanych w świecie naukowców z Franciszkańskiego Studium Biblijnego w Jerozolimie ${ }^{36}$. Jednym z ważniejszych celów twórców tego opracowania było uporządkowanie

${ }^{32}$ Por. P. J. Achtemeier, Bibbia in lingua italiana, art. cyt., 136; C. Buzzetti, C. Ghidelli, La traduzione..., dz. cyt., 114.

${ }^{33}$ Por. Wprowadzenie.

${ }^{34} \mathrm{Za}$ definicję kanonu aleksandryjskiego przyjmuje się Septuagintę, a ściślej - te jej księgi, które znalazły się w Wulgacie Świętego Hieronima. Księgi należące tylko do kanonu aleksandryjskiego nazwano w XVI wieku deuterokanonicznymi. Spetuaginta to zbiór ksiąg Starego Testamentu przetłumaczony zjęzyka hebrajskiego na język grecki na przełomie III i II wieku przed Chrystusem. Zawiera zarówno księgi kanoniczne, jak i deuterokanoniczne.

${ }^{35}$ Edycja posiada autoryzację właściwych władz katolickich, prawosławnych, protestanckich i żydowskich. Np. prof. dr Elio Toaff, naczelny rabin Rzymu, uznał że tłumaczeniem tym (Stary Testament) bez żadnych zastrzeżeń mogą posługiwać się żydzi dla ich duchowej formacji (na podstawie fotokopii listu dołączonej do wydania).

${ }^{36}$ Studium Biblicum Franciscanum. Wydział Nauk Biblijnych i Archeologii Papieskiego Ateneum Antonianum w Rzymie. Oficjalną działalność rozpoczęło w 1924 roku. Siedzibą ośrodka jest klasztor Ubiczowania przy ulicy Via Dolorosa na starym mieście w Jerozolimie. 
zamieszania, jakie wprowadziło pojawienie się na rynku wydawniczym dużej ilości tłumaczeń różniących się między sobą ${ }^{37}$. Język przekładu jest żywy i płynny, oddaje sens za sens, nie naruszając w niczym istoty tekstu w językach oryginalnych, ani - gdzie jest to tylko możliwe - formy wyrażeń oryginalnych. Dzięki konsekwentnym zabiegom uzyskano tekst odpowiadający oryginałowi, zachowano przejrzystość myśli, świeżość poezji. Całość stanowi doskonałe narzędzie w odczytywaniu orędzia biblijnego. To pierwszy w historii przekład Biblii na język włoski przeznaczony dla ludzi wszystkich wyznań i wszystkich ludzi dobrej woli ${ }^{38}$.

La Sacra Bibbia - miejsce i data: Watykan 1971; wydawca: Conferenza Episcopale Italiana ${ }^{39}$; źródła: przekład z języków oryginalnych (do opracowania wybrano istniejący już tekst Unione Tipografica-Editirce Torinese, uwzględniono też wersje LXX i Neo-Wulgaty ${ }^{40}$ oraz osiągnięcia współczesnej egzegezy); tłumaczenie: S. Bovo, G. Bressan, G. Canfora, S. Cipriani, F. Nardoni, N. Palmarini, A. Piazza, L. Randellini, F. Vattioni, S. Zedda; redakcja: A. Pangrazio, L. Cardini, M. Alberti; korekta literacka: P. Bargellini, A. M. Canopi, G. Devoto, M. Luzi, U. Marvaldi, B. Migliorini, F. Montanari, A. Mor, G. Pampaloni, L. M. Personò, G. Petrocchi, D. Pieraccioni, M. Puppo, P. Sacchi, G. Villani; korekta rytmiczna: P. Ernetti, E. Messore, L. Migliavacca, M. Vieri; komentarze i przypisy: S. Garofalo; wprowadzenia: zwięzłe do części, do ksiąg; przypisy: jako dodatek do każdej księgi. U podstaw propozycji dokonania nowego przekładu Biblii leżały potrzeby liturgii; sama myśl zrodziła się już podczas obrad Soboru Watykańskiego II $^{41}$. Wydanie

Uczelnia prowadzi prace w zakresie badań egzegetycznych, lingwistycznych i archeologicznych na terenie Izraela, Autonomii Palestyńskiej i w Jordanii.

${ }^{37}$ Por. Wprowadzenie.

${ }^{38}$ Por. tamże.

${ }^{39}$ Por. C. Buzzetti, C. Ghidelli, La traduzione..., dz. cyt., 115.

${ }^{40}$ Po Soborze Watykańskim II (1962-1965) powstała tzw. Nova Vulgata, tekst łaciński skorygowany w oparciu o hebrajski i grecki tekst oryginału. Wydana w 1979 roku za podstawę miała Wulgatę wydaną w 1969 roku przez B. Fishera oraz hebrajską Biblię Stuttgartensia (wyd. z 1967 roku), grecki przekład LXX (wyd. Rahlfs 1962), grecki Nowy Testament The Greek New Testament, wyd. 1966. Nowy Testament w formie eksperymentalnej został wydany w 1997 roku (L.E.V.).

${ }^{41}$ Por. E. D’Antonio, La traduzione..., dz. cyt., 99-105. Decyzja formalna zapadła 24 IX 1965. Komitet wykonawczy Konferencji Episkopatu Włoch rozpoczął przygotowania 
z 1971 roku (editio princeps), składa się z dwóch tomów: tom I zawierał Stary Testament i Nowy Testament, tom II - wprowadzenie i przypisy do tekstu, których nie było konieczności umieszczania w tomie 1 ze względu na jego charakter i szczególne (liturgiczne) przeznaczenie ${ }^{42}$. Nieznaczne poprawki pojawiły się w wydaniu z 1974 roku (editio minor) - ta wersja była rozpowszechniana aż do 1988 roku, kiedy to rozpoczęto pracę nad nowym, poprawionym wydaniem. Pełen tytuł precyzuje charakter wydania: La Sacra Bibbia. Versione italiana per l'uso liturgico a cura della Conferenza Episcopale Italiana. Po raz pierwszy i jak dotąd jedyny od czasów papieża Damazego I (około 305-384) i św. Hieronima (około 347-420) wydanie Biblii w języku narodowym dokonało się z inicjatywy i pod patronatem episkopatu ${ }^{43}$. Fakt ten czyni z niej edycję wyjątkową. Dyrektywy podjęte przez Konferencję Episkopatu Włoch w sposób bardzo przejrzysty wyznaczyły ramy nowego wydawnictwa: dokładność w przekładzie z języków oryginalnych, precyzja teologiczna, nowoczesność i piękno języka włoskiego, dźwięczność i harmonia tekstu, aby ułatwić jego proklamację, troska o rytm, co ma ułatwić opracowanie muzyczne tekstów (zwłaszcza psalmów) i ich chóralne wykonywanie w liturgii ${ }^{44}$. Prace grupy biblistów i językoznawców nad tekstem trwały od 1966 do 1971 roku. Do najważniejszych cech tego wydania należą m.in. zastosowanie odpowiedniej czcionki ułatwiającej czytanie tekstu podczas liturgii i przy innych okazjach, wykaz ksiąg odpowiadający temu, który został zastosowany w odnowionej liturgii (tam gdzie zachodziła konieczność, podano w nawiasach nazewnictwo ksiąg według Wulgaty), indeksy na początku ksiąg, zakładki z indeksami ułatwiające konsultacje ${ }^{45}$. W 1988 roku rozpoczęto prace nad nowym przejrzanym wydaniem, którego celem była aktualizacja tekstu w konfrontacji z Nowa Wulgata. Pracom grupy ekspertów przewodniczył G. Danielii ${ }^{46}$ W 1997 roku została zaprezentowana rewizja Nowego Testamentu dokonana

na poziomie narodowym do przygotowania jednolitego tekstu, który odpowiadałby warunkom lektury wspólnotowej, przede wszystkim liturgicznej.

${ }^{42}$ Por. Wprowadzenie, 14.

${ }^{43}$ Por. P. J. Achtemeier, Bibbia in lingua italiana, art. cyt., 136.

${ }^{44}$ Por. C. Buzzetti, C. Ghidelli, La traduzione..., dz. cyt., 115.

${ }^{45}$ Por. Wprowadzenie, 15.

${ }^{46}$ Por. C. Buzzetti, C. Ghidelli, La traduzione..., dz. cyt., 115. 
w oparciu o teksty greckie i o nowo odnalezione manuskrypty. Prace nad rewizją Starego Testamentu trwają nadal. Publikacja była przewidziana na 2007 rok, ale z powodu różnych trudności termin ten został przesunięty. W konfrontacji z innymi współczesnymi wydaniami Biblia Konferencji Episkopatu Włoch prezentuje tekst o najwyższych zaletach charakterystycznych dla naszej epoki. Z punktu widzenia egzegezy jest prawie zawsze dobra lub bardzo dobra, chociaż i ona ma swoje ograniczenia ${ }^{47}$. Jej słabą stroną jest brak rozwiniętych wprowadzeń i przypisów. Nie ulega wątpliwości, że poprzez tę edycję Kościół wykazał chęć i udowodnił umiejętność zaprezentowania słowa Bożego spisanego w sposób nowy i nowoczesny ${ }^{48}$.

La Bibbia di Gerusalemme - miejsce i data: Bolonia 1974; wydawca: Edizioni Dehoniane Bologna ${ }^{49}\left[{ }^{*}\right]$; źródła: przekład z języków oryginalnych (tekst tłumaczenia Konferencji Episkopatu Włoch z 1971 roku); wprowadzenia z francuskiego wydania La Bible de Jèrusalem z 1973 roku $^{50}$ : do części, do niektórych ksiąg; komentarz egzegetyczny; tytuły perykop i odnośniki na marginesie do tekstów paralelnych. Dzięki takiemu zabiegowi osiągnięto potrójny skutek: jak najszersze rozpowszechnienie oficjalnego przekładu Biblii zatwierdzonego przez Konferencję Episkopatu Włoch; wzbogacenie wersji biblijnej o wartościowy komentarz egzegetyczny; możliwość ciaggłej konfrontacji obu wydań. Uwagi dotyczące krytyki tekstowej, filologicznej, umiejętnie dostosowane przez biblistów włoskich, stanowią swoistą nowość, ponieważ odnotowują i uzasadniają przypadki, kiedy tekst Konferencji Episkopatu Włoch różni się od tekstu La Bible de Jèrusalem; $\mathrm{w}$ dodatku: tablice chronologiczne (22 strony), kalendarz, tablice miar i monet, indeks alfabetyczny najważniejszych imion, nazw i miejsc (10 stron), mapy geograficzne. Tekst biblijny oraz bogactwo, jak dotąd niedoścignione, komentarza egzegetycznego są bez wątpienia jednym z największych atutów tego wydania.

${ }^{47}$ Por. T. Lorenzin, “Studia Patavina” 22 (1975), 417-448.

${ }^{48}$ W 1969 roku powstała światowa organizacja katolicka z siedzibą w Stuttgarcie, która za cel przyjęła coraz lepszą i szerszą znajomość Biblii: World Catholic Federation for the Biblical Apostolate. Wydaje czasopismo "Word Event".

${ }^{49}$ Por. C. Buzzetti, C. Ghidelli, La traduzione..., dz. cyt., 115.

${ }^{50}$ La Bible de Jérusalem. La Sainte Bible traduite en français sous la direction de l'École Biblique de Jérusalem, Paris 1973. 
Bibbia TOB - miejsce i data: Turyn 1976; 1982; 1992 (wydania 3- i 1-tomowe); wydawca: LDC, Leumann ${ }^{51}$ [*]; źródła: tłumaczenie Konferencji Episkopatu Włoch z 1971 roku; tłumaczenie: dokładny wykaz tłumaczy (zarówno wydania francuskiego, jak i włoskiego) został podany w edycji z 1992 roku; wprowadzenia: do części, do ksiąg; u dołu strony: bogate przypisy; na marginesie: odnośniki; dodatki zaczerpnięte z TOB (Traduction Oecuménique de la Bible) z 1987 roku, w wydaniu z 1992 roku: tablica chronologiczna (13 stron), tablica miar i wag, indeks alfabetyczny głównych terminów (13 stron), mapy geograficzne. Księgi biblijne ułożone są w kolejności Biblii hebrajskiej: po księgach protokanonicznych Starego Testamentu następują księgi deuterokanoniczne, następnie księgi Nowego Testamentu ${ }^{52}$. Tekst Starego Testamentu został przetłumaczony z tekstu masoreckiego, odstępstwa od tej zasady odnotowane są w przypisach. W pisowni imion własnych i nazw geograficznych przyjęto sposób zastosowany w Biblii Konferencji Episkopatu Włoch. Ukazało się również wydanie jednotomowe pod tytułem Bibbia da studio TOB ${ }^{53}$.

La Bibbia - miejsce i data: Rzym 1974, 1978; wydawca: La Civiltà Cattolica $^{54}$; źródła: przekład z języków oryginalnych (tekst tłumaczenia Konferencji Episkopatu Włoch z 1974 roku); redakcja: P. Vanetti; wprowadzenia: ogólne, opis posługiwania się Biblią, do części, do ksiąg; na początku: graficzne tablice chronologiczne (12 stron); u dołu strony: zwięzłe przypisy; na marginesie: odnośniki; w dodatku: kalendarze, tablice-wskazówki do zastosowań liturgicznych, indeks analityczny (91 stron), mapy geograficzne, w tekście około 600 ilustracji, poza tekstem około 150 barwnych fotografii. Edycja jest w założeniu pomocą duszpasterską. Ten cel uzasadnia każdy element graficzny wydania, tekst biblijny jest tylko częścią całego tekstu. Zastosowano nowy typ komentarza: został on umieszczony w tekście i wyróżniony odrębną czcionką ${ }^{55}$ (na wzór wydania francuskiego). Mamy dzięki temu możli-

${ }^{51}$ Por. C. Buzzetti, C. Ghidelli, La traduzione..., dz. cyt., 116; P. J. Achtemeier, Bibbia in lingua italiana, art. cyt., 137.

${ }^{52}$ Taka kolejność skłoniła wydawców do umieszczenia podwójnego tłumaczenia Księgi Estery według tekstu hebrajskiego i greckiego.

${ }^{53}$ Por. P. J. Achtemeier, Bibbia in lingua italiana, art. cyt., 137.

${ }^{54}$ Por. C. Buzzetti, C. Ghidelli, La traduzione..., dz. cyt., 116.

${ }^{55}$ W wydaniu z 1974 roku były one drukowane większą czcionką, w wydaniu z 1978 roku są jedynie specjalnie oznaczone - por. C. Buzzetti, C. Ghidelli, La traduzione..., dz. 
wość jednoczesnego poznania zarówno kontekstu historycznego, jak i religijnego. Zabieg ten wydawcy tłumaczą przekonaniem, że nie wystarczy tylko dobry tekst biblijny, nie wystarczą tylko dobre przypisy, potrzeba komentarza, który przekona czytelnika do aktualności biblijnego przesłania ${ }^{56}$. Dobrze dobrany format, dobrej jakości papier, tekst w jednej kolumnie, estetyka kompozycji typograficznej i wspomniane wyżej bogate dodatki stanowią o szczególnej wartości tego wydania, czyniąc z niego bogate narzędzie w poznawaniu Biblii.

La Bibbia a cura dei Gesuiti di S. Fedele - miejsce i data: Mediolan 1980 (wydanie 10-tomowe); wydawca: Rusconi ${ }^{57}$; źródła: przekład z języków oryginalnych (tekst tłumaczenia Konferencji Episkopatu Włoch z 1974 roku); redakcja: P. Vanetti. Do tekstu dołączony jest specjalny komentarz, który nie jest zamieszczony w przypisach, ale wprowadza w wielkie sektory biblijne, w poszczególne księgi i w sekcje poszczególnych ksiąg. Wydanie bogato ilustrowane. Zawiera fotografie, mapy i teksty pozabiblijne.

Bibbia. Parola di Dio scritta per noi - miejsce i data: Turyn 1980 (wydanie 3-tomowe); wydawca: Marietti ${ }^{58}$; źródła: przekład zjęzyków oryginalnych (tekst tłumaczenia Konferencji Episkopatu Włoch z 1974 roku); wprowadzenia: opis posługiwania się Biblią, ogólne, do części, do ksiąg; u dołu strony: przypisy autorstwa L. Alonso-Schökela, T. Aurelia, C. Buzzettiego, V. Gattiego, G. Ghibertiego, C. Ghidelliego, B. Maggioniego, I. Paccomia, R. Penny, G. Prato, G. Ravasiego, U. Vanniego i innych; na marginesie: odnośniki biblijne; w dodatku: różnego rodzaju uzupełnienia ${ }^{59}$. W tomie I: tablica synoptyczna redakcji-tradycji, tablica synoptyczna praw Starego Testamentu, indeks liturgiczny, mapy geograficzne oraz tablice pozwalające rozpoznać miejsca biblijne. W tomie II: tablice chronologiczne wydarzeń, ksiąg, osób Starego Testamentu, instytucje Starego Testamentu w porządku alfabetycznym, indeks liturgiczny, mapy, ilustracje. W tomie III: tablice chronologiczne wydarzeń, ksiąg, osób Nowego Testamentu, tablice synoptyczne Ewangelii, instytucje Nowego

cyt., 116.

${ }^{56}$ Por. Wprowadzenie. Wydanie może służyć jako wzór do poszukiwań edytorskich.

${ }^{57}$ Por. Wprowadzenie.

${ }^{58}$ Por. C. Buzzetti, C. Ghidelli, La traduzione..., dz. cyt., 116.

${ }^{59}$ Por. Wprowadzenie, VIII. 
Testamentu, indeks analityczno-tematyczny, indeks historyczno-geograficzno-archeologiczny, indeks liturgiczny ogólny, mapy, ilustracje. Komentarz podkreśla orędzie teologiczne i znaczenie religijne, kładzie też spory nacisk na literacki aspekt tekstu. W Pięcioksięgu zaznaczono sigla poszczególnych warstw tradycji (J - jahwistycznej, E - elohistycznej, P - kapłańskiej i materiału redakcyjnego Rd) - ten zabieg edytorski wyróżnia to wydanie spośród innych ${ }^{60}$.

Bibbia per la formazione cristiana (szeroki wybór tekstów z Starego Testamentu i cały Nowy Testament) - miejsce i data: Bolonia 1993; wydawca: Edizioni Dehoniane Bologna ${ }^{61}$; źródła: przekład zjęzyków oryginalnych (tekst tłumaczenia Konferencji Episkopatu Włoch z 1971 roku); redakcja: P. Cobri, M. A. Cozzi, L. Chiarinelli, A. Filippi; wprowadzenia: ogólne, opis posługiwania się Biblią, do części, do ksiąg; na marginesie: uwagi z odnośnikami i powiązaniami; na stronach: uwagi-komentarze do części lub paragrafów; $w$ dodatku: opracowania Biblia, słowo Boże powierzone ludziom (44 strony) oraz Biblijny rozwój Credo (2 strony), indeks alfabetyczny tematów biblijnych (5 stron), indeks analityczny (50 stron), indeks liturgiczny ( 9 stron). Wydanie stanowi próbę realizacji postulatów zawartych w Katechizmie Kościoła katolickiego (109-119): zwrócenie uwagi na treść i godność całego Pisma Świętego, odczytanie Biblii w tradycji życiowej całego Kościoła, rozbudzenie umiejętności „,łuchania wiary”62.

La Bibbia - miejsce i data: Casale M. 1995; wydawca: Piemme ${ }^{63}$; źródła: przekład z języków oryginalnych (tekst tłumaczenia Konferencji Episkopatu Włoch z 1974 roku); redakcja: L. Pacomio, F. Dalla Vecchia, A. Pitta; wprowadzenia: ogólne, opis posługiwania się Biblią, do części, do indeksów; autorzy: A. Bonora, V. Gatti, C. Marcheselli-Casale, G. Odasso, S. Virgulin ${ }^{64}$; u dołu strony: obszerne przypisy; na marginesie: odnośniki; w dodatku: synteza teologiczna (po każdej księdze, po Starym Testamencie i po Nowym Testamencie), synopsa warstw

\footnotetext{
${ }^{60}$ Por. C. Buzzetti, C. Ghidelli, La traduzione..., dz. cyt., 116.

${ }^{61}$ Por. tamże.

${ }^{62}$ Por. Wprowadzenie, 12.

${ }^{63}$ Por. C. Buzzetti, C. Ghidelli, La traduzione..., dz. cyt., 116-117.

${ }^{64}$ Dokładny wykaz wszystkich nazwisk znajduje się w indeksie.
} 
tetrateuco ${ }^{65}$ ( 6 stron), synopsa tekstów prawnych Starego Testamentu (4 strony), synopsa czterech ewangelii (10 stron), tabela synoptyczna tekstów Pawłowych (5 stron), tablice chronologiczne (12 stron), słowniczek arecheologiczno-geograficzny (7 stron), wykaz badań archeologicznych (8 stron), opracowania: Biblia w katechezie i w szkole (15 stron), Biblia i liturgia (20 stron), Agape i Biblia (9 stron), bibliografia (23 stron), wykaz imion, nazw, miejsc (56 stron), indeks analityczno-tematyczny (48 stron); poza tekstem: 16 tablic i map geograficznych. Wydawcy podkreślają, że tekst Konferencji Episkopatu Włoch został wzbogacony uwagami krytycznymi i propozycjami jego ulepszenia. W tym celu do ekipy redakcyjnej zaproszono autorów dobranych według potrójnego kryterium: młodzi, narodowości włoskiej, specjaliści w dziedzinie biblistyki.

La Parola del Signore. Bibbia TILC (Traduzione interconfesionale in lingua corrente) - miejsce i data: Turyn-Rzym 1976 (Nowy Testament), 1985 (cała Biblia), 2001 (rewizja Nowego Testamentu); wydawca: LDC-ABU ${ }^{66}\left[{ }^{*}\right.$; źródła: przekład zjęzyków oryginalnych ${ }^{67}$; tłumacze: V. Bertalot, G. Boggio, A. Bonora, R. Caedo, M. Cimosa, B. Costabel, D. Garrone, C. Ghidelli, S. Lanza, M. La Posta, T. Lorenzin, R. Petraglio, S. Rapisarda, A. Soggin, P. F. Tagliacarne, P. Tamietti68; redakcja: J. De Waard, C. Buzzetti, J. C. Margot, współpraca: R. Bertalot, M. Cimos, M. Galizzi; wprowadzenia: krótkie do części, do ksiąg; u dołu strony: odnośniki i zwięzłe przypisy; w dodatku: słowniczek (10 stron), indeks analityczny (24 strony), tablica

${ }^{65}$ Niektórzy egzegeci wykluczają z Pięcioksięgu księgę Powtórzonego Prawa i zaliczają ją do ksiąg historycznych, stąd mamy Tetrateuch - Czteroksiąg.

${ }^{66}$ Por C. Buzzetti, C. Ghidelli, La traduzione..., dz. cyt., 117; P. J. Achtemeier, Bibbia in lingua italiana, art. cyt., 137. LDC - wydawnictwo salezjańskie Elledici z Turynu; ABU - Alleanza Biblica Universale (znana także jako U.B.S. - United Bible Societies), powstała w 1946 roku z połączenia wcześniejszych stowarzyszeń biblijnych, narodowych lub regionalnych, praktycznie w jednym celu: ułatwianie tłumaczenia, drukowania i rozpowszechniania Biblii. Obecnie do organizacji przynależy ponad 150 państw z całego świata.

${ }^{67}$ Korzystano z wydań krytycznych: Stary Testament - Biblia Hebraica Stuttgartiensia, Stuttgart 1967-1977. Nowy Testament - The Greek NT, ed. by K. Aland, M. Black, C. M. Martini, B. M. Metzger, A. Wigreen, Stuttgart 1975; dla ksiąg "deuterokanonicznych" - Septuaginta Vetus Testamentum Graecum, Göttingen 1931nn; Septuaginta. Id est Vetus Testamentum graece iuxta LXX interpretes, ed. A. Rahlfs, Stuttgart 1965.

${ }^{68} \mathrm{U}$ podstaw przekładu leży szeroka i głęboka refleksja lingwistyczna dokonana przez najlepszych specjalistów w tej dziedzinie - por. Zakończenie, 476. 
chronologiczna (4 strony), 15 map geograficznych. Edycja jest owocem współpracy grupy międzywyznaniowej (katolicy i protestanci) ${ }^{69}$, a także wymiany doświadczeń edytorskich i wydawniczych pomiędzy LDC i $\mathrm{ABU}^{70}$. Tłumaczenie według założeń wydawcy miało być zrozumiałe dla współczesnego odbiorcy i jednocześnie oddawać aspekty formalne języków oryginalnych ${ }^{71}$. Przekład daleki jest zatem od dosłowności, ale brak w nim arbitralnych dodatków, parafraz czy anachronizmów ${ }^{72}$. Posłużono się metodą tzw. ekwiwalencji metodycznej. A wszystko po to, by czytelnikowi nieobeznanemu z tradycyjnym językiem biblijnym umożliwić jego zrozumienie ${ }^{73}$. Istnieją dwie wersje wydania: bez ksiąg deuterokanonicznych (dla chrześcijan, którzy kanon Stary Testament ograniczają do kanonu hebrajskiego) i z księgami deuterokanonicznymi (ta wersja prezentowana jest w oparciu o ustalenia z 1968 roku między ABU i rzymskim Sekretariatem do spraw Jedności (hrześcijan) ${ }^{74}$. Edycja zyskała niezwykłą i nieoczekiwaną popularność, która trwa nadal ${ }^{75}$. Przyczyn tego sukcesu upatruje się kilka: wiele osób niemających właściwego przygotowania naukowego pragnęło zbliżyć się do Biblii w przyjaznej, nie odstraszającej formie językowej i kulturowej; związek z Kościołem: pomysł, wykonanie i ostateczny rezultat były poddane autorytetom katolickim i protestanckim; wyraźna deklaracja twórców, że wydanie to nie chce zastąpić innych dotychczasowych dobrych tłumaczeń, zwłaszcza tych oficjalnych: faktycznie, Biblia ta nadaje się bardziej do lektury medytacyjnej niż naukowej ${ }^{76}$.

${ }^{69}$ Jest również mowa o okazjonalnej współpracy z Żydami w kwestiach kanonu Starego Testamentu oraz słowniczka do Nowego Testamentu - por. Zakończenie, 477.

${ }^{70}$ Por. Wprowadzenie, 7.

${ }^{71}$ Pewne aspekty, które mogą być interesujące i ważne dla specjalistów, nie są takimi dla przeciętnego czytelnika, stąd nacisk przede wszystkim na znaczenie terminów.

${ }^{72}$ Por. Zakończenie, 476.

${ }^{73}$ Por. Wprowadzenie, 7.

${ }^{74}$ Tekst dokumentu można przeczytać w „Rivista Biblica” 16 (1968), 317-326.

${ }^{75} \mathrm{~W}$ ciągu pierwszych trzech lat sprzedaży rozpowszechniono prawie trzy miliony egzemplarzy.

${ }^{76}$ Więcej o tym wydaniu por. A. Ablondi, L'avventura della Parola di Dio nella chiesa e nell'ecumensimo, Torino 1982. 
La Bibbia. Nuovissima versione dai testi originali - miejsce i data: Rzym 1983; wydawca: Edizioni Paoline ${ }^{77}$ [*]; źródła: przekład z języków oryginalnych; tłumaczenie: G. Bernini, S. Cavalletti, G. Danieli, N. Loss i inni ${ }^{78}$; wprowadzenia: do części, do ksiąg; u dołu strony: zwięzłe przypisy autorstwa A. Girlandy, P. Gironiego, F. Pasquero, G. Ravasiego, P. Rossano, S. Virgullina; w dodatku: indeks analityczny podstawowych terminów biblijnych (74 strony), indeks podstawowych nazw własnych, tablica chronologiczna (4 strony), mapy geograficzne. W latach 1967-1980 Edizioni Paoline we współpracy z włoskimi ekspertami włoskami opublikowało Biblię w 48 tomach. Pomysł wydania nakreślił i promował ks. Giacomo Alberione (1884-1971), założyciel Società San Paolo. W prezentacji wykorzystano wzór edytorski zaczerpnięty z zeszytowej wersji Bible de Jérusalem. Do tekstu dodano bardzo rozwinięty komentarz, który czytelnikowi mało obeznanemu ze światem biblijnym wyjaśniał terminy, imiona, trudniejsze i wieloznaczne wyrażenia, umożliwiając lekturę w sposób ciągły ${ }^{79}$. Samo tłumaczenie tekstu, wzbogacone o krótkie, konkretne wprowadzenia i specjalnie dopracowane uwagi, opublikowano w 1983 roku w jednym tomie pod taką samą nazwą. Ta właśnie edycja była wielokrotnie wznawiana, i to w dużych nakładach ${ }^{80}$. W 1991 roku cały wcześniejszy 48-tomowy zbiór został wydany w czterech wielkich tomach. Tom I: Antico Testamento: Pentateuco-Libri storici; tom II: Antico Testamento: Libri sapienziali-Libri profetici; tom III: Nuovo Testamento; tom IV: Sussidi, zamieszczono tu różnego rodzaju dodatki i uzupełnienia ${ }^{81}$. Tekst, nieznacznie poprawiony w stosunku do pierwszego wydania, stara się odzwierciedlać teksty $\mathrm{w}$ językach oryginalnych łącznie $\mathrm{z}$ ich surowością, niezgrabnościami konstrukcyjnymi, mentalnością i sposobem wyrażania się odległymi od współczesnej epoki i kultury. Ponieważ w pracy nad przekładem nie można było uwzględnić wszystkich elementów związanych z interpretacją tekstu i pobocznymi problemami, wzięto więc pod uwagę tylko najważniejsze warianty tekstowe istniejące

${ }^{77}$ Por. C. Buzzetti, C. Ghidelli, La traduzione..., dz. cyt., 117-118; P. J. Achtemeier, Bibbia in lingua italiana, art. cyt., 136.

${ }^{78}$ Dokładny wykaz nazwisk zawiera lista współpracowników.

${ }^{79}$ Por. Wprowadzenie, VII.

${ }^{80}$ Por. tamże.

${ }^{81}$ Por. tamże. 
w najstarszych kodeksach i wersjach. W przypadkach opcji znacznie odbiegających od dotychczasowych starano się także uzasadnić decyzję tłumaczy. Te krótkie krytyczne uwagi umieszczone zostały między tekstem biblijnym a komentarzem ${ }^{82}$. Na początku każdego tomu dołączono wykaz skrótów stosowanych w aparacie krytycznym, w bibliografii, w przypisach. Na marginesie tekstu umieszczono odnośniki do tekstów paralelnych ${ }^{83}$. Największą pomocą w zrozumieniu historycznej, literackiej i religijnej wymowy Biblii są wprowadzenia do poszczególnych ksiąg i do grup ksiąg ${ }^{84}$. Komentarz dostosowano do poziomu osób o przeciętnym wykształceniu. Ma on charakter interpretacji historyczno-teologicznej. Zazwyczaj każdy fragment czy jednostka literacka zostaje krótko omówiona pod kątem treści i struktury. Po tym następuje wyjaśnienie poszczególnych wersetów, terminów i wyrażeń, które tego wymagają. Są również uwagi poza komentarzem: naświetlają one problemy historii i teologii biblijnej, ważne i godne podkreślenia, chociażby w formie syntetycznej ${ }^{85}$. W tomie 4 zostały zebrane pożyteczne dodatki: mały atlas biblijny, tablica chronologiczna zestawiająca w sposób syntetyczny wydarzenia biblijne oraz bliskowschodniej kultury starożytnej i klasycznej, kanon ksiąg biblijnych w tradycji hebrajskiej i chrześcijańskiej, tabele miar, wag, monet świątynnych, synopsa czterech ewangelii, indeks liturgiczny, indeks analityczny tematyczno-onomastyczny ${ }^{86}$.

La Bibbia per la Famiglia - miejsce i data: Mediolan 1993-1999; wydawca: Famiglia Cristiana ${ }^{87}$; źródła: przekład oparty na tekście La Bibbia. Nuovissima versione dai testi originali, Edizioni Paoline, Rzym 1983; redakcja: G. Ravasi, współpraca: L. Ancona, F. Ardusso, B. Bertoli, E. Biagi, F. Casavola, R. Cavedo, I. A. Chiusano, R. Copioli, S. Dianich, F. Facchini, R. Falsini, G. Lagorio, E. Lodi, L. Lorenzetti, B. Maggioni, B. Marconcini, G. Mattai, G. Panteghini, G. Piana, B. Placido, M. Prisco, M. R. Stern, A. Rolla, L. Alonso-Schökel, A. Serra, S. Sirbioni, P. Stefani, J. L. Ska, T. Tentori, D. M. Turoldo, S. Virgulin; komentarz: G. Ravasi;

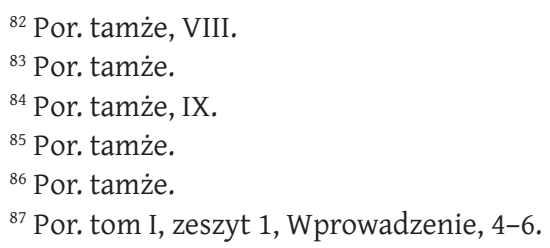


noty objaśniające: P. Gironi, F. Serafini; konsultacje ikonograficzne: P. De Benedetti, H. Pfeiffer, S. Sabatucci, T. Verdon; projekt graficzny: C. Toresani, I. Quagliarella. Wydanie zeszytowe, oryginalne, absolutnie nowe w swojej formie graficznej i edytorskiej, umożliwia czytelnikom samodzielne odkrywanie znaczenia Biblii, stanowi narzędzie do pogłębienia wiedzy o Piśmie Świętym, studiowania go w rodzinie i we wspólnotach kościelnych. W centrum każdej stronicy znajduje się część zasadnicza - wyróżniony graficznie tekst biblijny, od którego należy rozpoczynać lekturę. Jego brzmienie jest zbliżone do oryginału, choć za cenę pewnej surowości. Po lewej stronie tekstu biblijnego znajduje się rodzaj opowiadania autorstwa G. Ravasiego, który objaśnia treść w sposób zwięzły i zrozumiały dla współczesnego czytelnika. Po prawej stronie umieszczono listę tematów, symboli, miejsc, postaci oraz ciekawostek, które kryje w sobie tekst biblijny. Są to zazwyczaj zwięzłe hasła, nierzadko wzbogacane ilustracjami, które mogą funkcjonować jako obszerny słownik czy nawet rodzaj encyklopedii biblijnej. Na zakończenie każdego bloku rozdziałów następuje rodzaj podsumowania. Pozwala ono przemyśleć napotkane tematy teologiczne, moralne, duchowe wyłaniające się z tekstu biblijnego i ważne dla zrozumienia dziejów wiary Starego i Nowego Testamentu. Wydanie jest ilustrowane reprodukcjami dzieł sztuki. W dalszej kolejności został podana syntetyczna wersja tekstu biblijnego dla dzieci pełniąca rolę pomocy dla rodziców i katechetów w przekazywaniu biblijnego orędzia wiary. Całość zamyka wypowiedźktóregoś ze znanych pisarzy lub współczesną osobistość będąca świadectwem wiary i potwierdzeniem niezmiennej aktualności słowa Bożego.

La Sacra Bibbia. Versione Nuova Riveduta - miejsce i data: Genewa 1994; Rzym 19958, wydawca: Società Biblica di Ginevra (wydanie z 1994 roku), Società Biblica B.\&F. (wydanie z 1995 roku); źródła: przekład z języków oryginalnych; współpracownicy: brak listy; wprowadzenia: ogólne, opis korzystania z Biblii; u dołu strony: odnośniki i krótkie przypisy (z zaznaczeniem w tekście biblijnym); w dodatku: mapy geograficzne kolorowe; edycja jest korektą La Sacra Bibbia. Versione Riveduta.

${ }^{88}$ Por. C. Buzzetti, C. Ghidelli, La traduzione..., dz. cyt., 118. 
La Bibbia. Edizione condensata di Selezione del Reader's Digest ${ }^{89}$ - miejsce i data: Mediolan 1995; tekst i wprowadzenia: G. Ravasi (do Starego Testamentu), G. Saldarini (do Nowego Testamentu); wprowadzenia: ogólne do Starego Testamentu, ogólne do Nowego Testamentu, do ksiąg; w dodatku: indeks ogólny, indeks analityczny, słownik terminów i wyrażeń. Edycja różni się od innych tym, że zawiera tekst skondensowany. Ta szczególna technika pozwala na to, by był on krótki, płynny. Aby uzyskać taki efekt, z tekstu usunięto słowa, zdania, powtórki, których brak jednak w żaden sposób nie ujmuje zasadniczej treści. Wydawcy wyszli z założenia, że są w Biblii części odpowiednie, ważne, interesujące dla poszukiwań naukowych, dla uważnych badaczy, które mogą być spokojnie opuszczone, gdy Biblia zostaje ukierunkowana na szerokie grono odbiorców. Kondensacja nastąpiła w oparciu o tekst zatwierdzony przez Konferencję Episkopatu Włoch. Specyficzną cechą tego wydania jest brak podziału tekstu na rozdziały i wiersze.

Oprócz wymienionych tłumaczeń Biblii najęzyk włoski istniejąjeszcze inne ${ }^{90}$. Odrębną grupę wydań Biblii stanowią tłumaczenia interlinearne, które nie są przekładami w ścisłym sensie, ale bez wątpienia stanowią cenną pomoc dla tłumaczy ${ }^{91}$.

${ }^{89}$ Por. Wprowadzenie, 9.

${ }^{90}$ Np. Bibbia Emmaus, wyd. San Paolo 1998, jednotomowa - tekst: Nuovissima versione dai testi originali w jednej kolumnie, w dwóch kolorach; obszerne wprowadzenia: do całości, do poszczególnych ksiąg; obszerne przypisy w dwóch kolumnach; teksty paralelne na marginesie; indeks analityczny: pojęcia, fakty, nazwy, słowniczek. Bibbia Tabor, wyd. San Paolo 1999, jednotomowa - tekst: forma skrócona Nuovissima versione dai testi originali w dwóch kolumnach; przypisy: forma skrócona z Bibbia Emmaus; indeks analityczny. Bibbia Ebron, wyd. San Paolo 2000, jednotomowa - tekst: Nuovissima versione dai testi originali; wzbogacone wprowadzenia: ogólne do Biblii, do Starego Testamentu, do Nowego Testamentu, do poszczegółnych grup ksiąg biblijnych; przypisy; teksty paralelne; indeks tematyczny; mapy; chronologia biblijna; miary, wagi i monety. I libri di Dio, wyd. Oscar Mondadori 2000, sześć tomów - przypisy: brak; wprowadzenia: bardzo rozbudowane; dzieło grupy młodych naukowców i badaczy z różnych uniwersytetów papieskich, którzy przetłumaczyli tekst biblijny z języków oryginalnych na współczesny język włoski.

${ }^{91}$ Do najważniejszych opracowań tego typu należą: tłumaczenie pod red. jezuity G. Savoca Psalmów (1983) i Księgi Rodzaju (1995); edycja z 1998 roku (San Paolo); zawiera tekst grecki według GreekNew Testament z 1993 roku; tekst łaciński Wulgaty Klementyńskiej; tekst włoski według Nuovissima versione, przekład interlinearny A. Bigarelli. Seria Bibbia Ebraica Interlineare, wyd. San Paolo, wydawana od 2001 roku pod red. P. Beretty (do- 
Na zakończenie postawmy jeszcze jedno pytanie: dlaczego powstają nowe przekłady Biblii, skoro istnieją już inne, wcześniejsze? Cele przyświecające autorom przekładów i wydawcom możemy sprowadzić do trzech zasadniczych ${ }^{92}$ : po pierwsze, chęć wykorzystania rezultatów nowych badań naukowych, zarówno z dziedziny krytyki tekstu (pozwalają one na większe zbliżenie się do tekstu oryginalnego), jak i z dziedziny egzegezy i dziedzin pokrewnych (stanowią cenną pomoc dla poprawnej interpretacji tekstu); po drugie, nowa edycja jest próbą uzupełnienia tekstu biblijnego wskazówkami historycznymi, literackimi i teologicznymi, które stanowią bardzo cenne wprowadzenie w świat Biblii i pozwalają na jej lepsze zrozumienie (chodzi zatem o wymiar dydaktyczno-katechetyczny); po trzecie, tłumaczenia już istniejące posługują się językiem różnym od współczesnego, nowe wydania starają się temu zaradzić bądź poprzez korektę wersji wcześniejszych, bądź poprzez przygotowanie wersji zupełnie nowych. Odnosi się jednak wrażenie, że współczesnym przekładom włoskim brak jest niekiedy głębokiej i odpowiedniej refleksji lingwistycznej. Tego rodzaju założenia przyświecające twórcom nowych wydań sprawiły, że we Włoszech brak jest obecnie starań o zachowanie i rozpowszechnianie edycji dawnych ${ }^{93}$.

Oddzielną kwestię stanowią adresaci nowych edycji. W przypadku wielu współczesnych przekładów trudno jest ustalić, do kogo są faktycznie skierowane: pewne cechy zachęcają bowiem do ich szerokiego propago-

tychczas ukazały się księgi: Wyjścia, Powtórzonego Prawa, Kapłańska, Liczb, Rodzaju); zawiera tekst hebrajski Biblia Hebraica Stuttgartensia; przekład interlinearny karmelity C. Doveriego, tekst grecki według LXX (wyd. A. Rahlfs), tekst łaciński według Wulgaty Klementyńskiej, tekst włoski według Nuovissima versione (do tekstu sporo zastrzeżeń mają znani włoscy egzegeci, np. G. Ravasi). Seria Bibbia TINTI (Traduzione INTerlineare Italiana), wyd. Edizioni Dehoniane Bologna, od 2001 roku pod red. R. Reggi; dotychczas opublikowano księgi Wyjścia, Rodzaju, Psalmów (z wprowadzeniem G. Ravasiego), Proroków Mniejszych, Izajasza; zawiera tekst hebrajski, aramejski, według Biblia Hebraica Stuttgartensia; grecki według Septuaginty A. Rahlfsa, tekst włoski na bazie tłumaczeń Konferencji Episkopatu Włoch, Diodati, Garofalo, TOB; u dołu strony zamieszczony jest tekst tłumaczenia Konferencji Episkopatu Włoch.

${ }^{92}$ Por. tamże, 92-95.

${ }^{93}$ Wyjątek stanowi Biblia Diodati (1607) bardzo bliska wielu włoskim ewangelikom; wśród katolików podobnym sentymentem darzony jest łaciński przekład św. Hieronima Wulgata. 
wania, inne natomiast czynią z nich narzędzia zarezerwowane wyłącznie dla wąskiego grona specjalistów, znawców języków i kultury biblijnej ${ }^{94}$.

Które zatem tłumaczenie Biblii wybrać? Udzielenie odpowiedzi jest niezwykle trudne, także z braku jednomyślnych kryteriów. Można jednak wskazać przynajmniej na trzy elementy, które wydają się być powszechnie uznawane: traktowanie materiału tekstowego w sposób odpowiedzialny i udokumentowany; egzegeza, która jest teologicznie uzasadniona i daleka od opinii niemających szerokiego poparcia na polu biblijnym i językowym; stosowanie w przekładzie języka rzeczywiście będącego obecnie w użyciu ${ }^{95}$.

Pytanie o wybór tłumaczenia Biblii należy uzupełnić dodatkowym: dla kogo i na jaki użytek ma być przeznaczone? Biblia bowiem jest używana w różnych okolicznościach, publicznie i prywatnie, dlatego wydanie odpowiednie w jednej sytuacji może nie odpowiadać oczekiwaniom w innej. Najlepszym zatem przekładem Biblii będzie ten, który najtrafniej komunikuje orędzie biblijne konkretnemu odbiorcy ${ }^{96}$.

Rzym

RYSZARD WRÓBEL OFMCONV

\section{Słowa kluczowe}

Biblia, Pismo Święte, Ewangelia, źródło, tłumaczenie, przekład, edycja, wydawca, redakcja, komentarz, egzegeza, Włochy

\section{Summary}

Bible translations into Italian (20th century)

Discussing twentieth-century translations of the Bible into Italian we have to make a crucial distinction: there are different translations and different editions; the latter are more numerous, as the same translation may appear in different forms. For many of them it is difficult to determine to whom they are addressed: some of the features

\footnotetext{
${ }^{94}$ Por. C. Buzzetti, La Bibbia..., dz. cyt., 100.

${ }_{95}$ Por. L. Fanin, Quale traduzione della Bibbia preferire?, „Rivista Biblica” 28 (1980), 428-433.

${ }^{96} \mathrm{~W}$ świetle tych uwarunkowań należy oceniać opracowania specyficzne, np. La Bibbia del fanciullo, Torino 1956 (red. Tintori); J. Ecker, La Bibbia per la gioventù, Torino 1975. Pierwsza z nich jest cenną pomocą w obszarze katechezy, ale powinna być prezentowana jako rodzaj komentarza, a nie tekst biblijny w ścisłym tego słowa znaczeniu.
} 
show a broad willingness to promote the content of the Bible, while others make them a tool only for a group of specialists.

The article discusses the issue of the Bibles, which were printed in Italy in the twentieth century; there were 27. It deliberately does not include translations and elaborations less prevalent or partial studies for professionals.

The information is presented in a tangible and transparent scheme, which facilitates their mutual compatibility. Each description contains the name or title of work, author's name, place and date of publication, publisher's name, names of translators, editors, source of translation, editing characteristics, and other observations.

\section{Keywords}

Bible, Holy Scripture, Gospel, source, translation, editing, editor, redaction, commentary, exegesis, Italy 
